\title{
Article \\ Proline Concentration and Its Metabolism Are Regulated in a Leaf Age Dependent Manner But Not by Abscisic Acid in Pea Plants Exposed to Cadmium Stress
}

\author{
Edyta Zdunek-Zastocka *, Agnieszka Grabowska, Beata Michniewska and Sławomir Orzechowski iD \\ Department of Biochemistry and Microbiology, Warsaw University of Life Sciences-SGGW, \\ Nowoursynowska 159, 02-776 Warsaw, Poland; agnieszka_grabowska@sggw.edu.pl (A.G.); \\ beata_michniewska@sggw.edu.pl (B.M.); slawomir_orzechowski@sggw.edu.pl (S.O.) \\ * Correspondence: edyta_zdunek_zastocka@sggw.edu.pl; Tel.: +48-22-593-2577
}

Citation: Zdunek-Zastocka, E.; Grabowska, A.; Michniewska, B.; Orzechowski, S. Proline Concentration and Its Metabolism Are Regulated in a Leaf Age Dependent Manner But Not by Abscisic Acid in Pea Plants Exposed to Cadmium Stress. Cells 2021, 10, 946. https://doi.org/10.3390/ cells10040946

Academic Editor:

Suleyman Allakhverdiev

Received: 28 February 2021

Accepted: 16 April 2021

Published: 20 April 2021

Publisher's Note: MDPI stays neutral with regard to jurisdictional claims in published maps and institutional affiliations.

Copyright: (c) 2021 by the authors. Licensee MDPI, Basel, Switzerland. This article is an open access article distributed under the terms and conditions of the Creative Commons Attribution (CC BY) license (https:/ / creativecommons.org/licenses/by/ $4.0 /)$.
Abstract: The accumulation of proline is one of the defense mechanisms of plants against the harmful effects of adverse environmental conditions; however, when pea plants were treated for $12 \mathrm{~h}$ with $\mathrm{CdCl}_{2}$, the proline concentration decreased in the youngest $\mathrm{A}$ (not expanded) and B1 (expanded) leaves, and did not change significantly in the B2 (mature, expanded) or C (the oldest) leaves. After $24 \mathrm{~h}$ of cadmium (Cd) stress, the proline concentration remained low in A and B1 leaves, while in B2 and $C$ leaves, it increased, and after $48 \mathrm{~h}$, an increase in the proline concentration in the leaves at each stage of development was observed. The role of proline in the different phases of plant response to the $\mathrm{Cd}$ treatment is discussed. Changes in proline accumulation corresponded closely with changes in the transcript levels of PsP5CS2, a gene encoding D1-pyrroline-5-carboxylate synthetase involved in proline synthesis, and PSPDH1, a gene encoding proline dehydrogenase engaged in proline degradation. $\mathrm{CdCl}_{2}$ application induced the expression of PsProT1 and PsProT2, genes encoding proline transporters, especially during the first $12 \mathrm{~h}$ of treatment in A and B1 leaves. When the time courses of abscisic acid (ABA) and proline accumulation were compared, it was concluded that an increase in the proline concentration in the leaves of Cd-treated pea plants was more related to a decrease in chlorophyll concentration (leaves B2 and C) and an increase in the malondialdehyde level (A and B1 leaves) than with an increase in ABA concentration alone. Exogenous application of ABA $(0.5,5,50 \mu \mathrm{M})$ significantly increased the proline concentration in the A leaves of pea plants only, and was accompanied by an elevated and repressed expression of PSP5CS2 and PSPDH1 in these leaves, respectively. The presented results suggest that under Cd stress, the accumulation of proline in leaves of pea plants may take place independently of the ABA signaling.

Keywords: abscisic acid; cadmium; heavy metals; malondialdehyde; Pisum sativum L.; pyrroline-5carboxylate synthetase; proline dehydrogenase; proline transporters

\section{Introduction}

Over the past few decades, increased anthropogenic activity, rapid industrialization, and the use of metal-based pesticides have led to an increased contamination of soil and water with heavy metals, which in turn causes toxicity to living organisms [1,2]. Among them, cadmium (Cd) is one of the most common heavy metals in a contaminated environment, which negatively affects plant growth and development, even when available in low concentrations. From the soil, $\mathrm{Cd}$ can be easily taken up by plants, leading to severe disturbances in plant physiological and biochemical processes [3,4]. Cd inhibits photosynthesis and transpiration in leaves [4], limits water uptake, and disrupts the uptake and movement of mineral nutrients [5]. At the cellular level, Cd toxicity can be explained by its ability to react with the sulfhydryl groups of proteins, replacement of some essential elements at the active sites of enzymes, and replacement of magnesium in both chlorophyll a and $b[4,6]$. Although $\mathrm{Cd}$ is not a redox-active metal, it can induce oxidative stress, 
possibly by interfering with an antioxidant defense, by increasing nicotinamide adenine dinucleotide phosphate (NADPH) oxidase activity, or by disrupting the electron transport chain $[7,8]$.

To counteract the deleterious effects of adverse environmental conditions, plants have evolved multiple defense mechanisms. Among these, a crucial role is played by the synthesis of protective compounds, including specific amino acids such as proline, peptides such as glutathione and phytochelatins, and polyamines such as putrescine [9,10]. Stress-induced proline accumulation has been confirmed in many plant species and has been associated with adaptation, particularly to osmotic stress caused by drought or salinity or simulated by polyethylene glycol (PEG) $[9,11]$. Apart from being one of the most widespread compatible osmolytes, proline may contribute to scavenging reactive oxygen species (ROS), stabilizing proteins and subcellular structures, and regulating intracellular redox potential, and it may function as a signaling molecule or heavy metal chelator [9,11-14].

Under stress conditions, proline is synthesized mainly from glutamate, which is reduced to glutamate semialdehyde by the rate-limiting D1-pyrroline-5-carboxylate synthetase (P5CS), and then spontaneously converted to pyrroline-5-carboxylate (P5C) and reduced to proline by P5C reductase $[12,15]$. In plants, P5CS is typically encoded by two genes that exhibit distinctive expression patterns, suggesting different metabolic functions. In Arabidopsis thaliana, transcription of AtP5CS1 is induced under drought, salinity and phosphate deficiency, whereas AtP5CS2 is upregulated during incompatible plant-pathogen interactions [16-21]. Moreover, $p 5 c s 1$ mutants have shown a reduction in stress-induced proline accumulation and hypersensitivity to salt stress, while $p 5 c s 2$ mutation caused embryo abortion upon seed development [22]. In Medicago truncatula, transcript abundance of MtP5CS1 was unaffected by osmotic stresses, in contrast to MtP5CS2, which expression was strongly induced in shoots of salt-stressed plants [23].

Proline catabolism occurs through the action of proline dehydrogenase (PDH), which oxidizes proline to $\mathrm{P} 5 \mathrm{C}$, and by $\mathrm{P} 5 \mathrm{C}$ dehydrogenase (P5CDH) converting $\mathrm{P} 5 \mathrm{C}$ to glutamate. In Arabidopsis and Medicago sativa, $\mathrm{PDH}$ is encoded by two genes, while P5CDH exists as a single copy gene [24,25]. During salt stress, expression of both MsPDHs strongly decreased and was closely correlated with proline accumulation, whereas transcript levels of MsP5CDH remained unchanged [25]. In Arabidopsis, both ProDHs were induced by exogenous proline; however, $\mathrm{NaCl}$ was found to repress ProDH1 and induce ProDH2 [21,24,26,27]. Interestingly, the Arabidopsis pdh1 mutant displayed hypersensitivity to proline despite the presence of $A t P D H 2$, emphasizing the role of AtPDH1 in proline catabolism [28].

Based on current knowledge, the reactions catalyzed by P5CS and PDH are the rate-limiting steps in proline biosynthesis and degradation, respectively, under stressful conditions [12]. However, the intracellular proline concentration is the cumulative result of not only the rates of biosynthesis and degradation, but also transport between cells and organs $[29,30]$. The three Arabidopsis proline transporters (ProTs) are localized at the plasma membrane and mediate the transport not only of proline, but also of glycine betaine and $\gamma$-aminobutyric acid [31]. Transcripts of AtProT1 have been found in the phloem or phloem parenchyma cells, indicating a role in the long-distance transport of solutes [31], whereas expression of AtPro2 as well as GmProT1 and GmProT2 in alfalfa has been found to be strongly induced in response to salt and drought, implying an important role in nitrogen distribution under stress conditions [31,32].

Although accumulation of proline under osmotic stress is a well-known phenomenon, the results describing the changes in proline concentration due to cadmium toxicity are often contradictory, especially in the leaves. Cadmium has been found to significantly increase proline accumulation in the leaves of sunflower [33], cucumber [34], and bean seedlings [35], while reduced proline concentration was observed in the leaves of oilseed rape [36], wheat [37], and hybrid poplar [38]. The influence of cadmium on proline concentration was investigated after several days or weeks of treatment; hence, differences may have resulted from the differing roles of this multifunctional amino acid [11] at individual stages of adaptation to unfavorable conditions. There is a shortfall of information on the 
dynamics of changes in proline concentration in the first $48 \mathrm{~h}$ of cadmium exposure, and even less is known about the metabolism and transport of proline under these conditions. Moreover, the analysis of leaves at different stages of development would provide new information enabling an understanding of the role of proline in the early response of a plant to Cd ions.

Some results have demonstrated that accumulation of proline under osmotic stress can be mediated by abscisic acid (ABA) [39,40]. Under drought stress, transgenic Arabidopsis and petunia plants overexpressing NCED (9-cis-epoxycarotenoid dioxygenase), a rate-limiting gene in $\mathrm{ABA}$ biosynthesis in response to stress, accumulated significantly more proline than did wild-type (WT) plants [41,42]. Moreover, treatment with norflurazon, an ABA synthesis inhibitor, inhibited proline synthesis and aggravated hypoxia-induced oxidative damage in rice roots [43]. However, the use of ABA-insensitive mutants (abi1-1, abi2-1, abi3, abi4, abi5) shows that proline accumulation under low water potential was dependent not only on the ABA concentration, but also on the plant sensitivity to this hormone [44]. Furthermore, in ABA-deficient aba1-1 mutants, the expression of the genes involved in proline biosynthesis was independent of the endogenous level of ABA in Arabidopsis under cold and osmotic stresses [45]. It was also reported that ABA alone was not able to duplicate drought-induced proline accumulation [46], and the application of exogenous ABA did not increase the proline concentration in barley or spinach [47]. Therefore, at least under drought, cold, or PEG-induced osmotic stresses, proline accumulation is mediated both by ABA-dependent and ABA-independent signaling pathways. Under conditions of $\mathrm{Cd}$ toxicity, however, it is not known whether there are any interactions between $\mathrm{ABA}$ and proline accumulation or whether the metabolism of proline and its transport are ABA-independent.

Therefore, the present study investigates the possible mediating role of ABA in the regulation of proline accumulation and its metabolism in the early stages of $\mathrm{Cd}$ toxicity in pea leaves at various stages of development. First, the dynamics of changes in ABA concentration with changes in proline accumulation and the expression of genes related to its metabolism and transport during the first $48 \mathrm{~h}$ of $\mathrm{Cd}$ treatment were investigated, and relationships between these variables were explored. Subsequently, the effects of exogenous ABA application on proline concentration and expression of genes related to its metabolism and transport were examined.

\section{Materials and Methods}

\subsection{Plant Material and Experimental Conditions}

Seeds of Pisum sativum L. (cv. Iłówiecki) were germinated in moist vermiculite, and the 12-day-old seedlings were transferred to containers filled with aerated 1/2 Hoagland medium [48]. After two days, the medium was supplemented with $\mathrm{CdCl}_{2}(50 \mu \mathrm{M})$ or ABA $(0.5,5$, or $50 \mu \mathrm{M})$. Plants grown in a medium without $\mathrm{CdCl}_{2}$ or $\mathrm{ABA}$ served as controls. After 12, 24, and $48 \mathrm{~h}$ of the treatments, plants (twelve plants per treatment) were harvested and separated into roots and leaves (leaflets plus stipule). The leaves were grouped according to the stage of development. The oldest true leaves were collected from the first node from the bottom and were termed $C$ leaves. Leaves taken from the second and third nodes were termed B2 leaves. The youngest fully expanded leaves were collected from the fourth node and were termed B1 leaves, while the youngest unexpanded leaves were taken from the fifth node and were termed A leaves. The root and leaf samples were frozen in liquid $\mathrm{N}_{2}$ immediately after harvest and stored at $-80{ }^{\circ} \mathrm{C}$ until use.

The experiments were conducted in a plant growth chamber (the MLR-352H Climate Chamber, PHC Biomedical-formerly Panasonic Biomedical) at a humidity of approximately $60 \%$ and light intensity of $300 \mu \mathrm{mol} \mathrm{s}^{-1} \mathrm{~m}^{-2}$. The air temperature was $22{ }^{\circ} \mathrm{C}(16 \mathrm{~h})$ during the day and $19{ }^{\circ} \mathrm{C}(8 \mathrm{~h})$ at night. The experiment (all treatments) was repeated independently at least three times, giving at least three independent biological replicates. A minimum of two technical replicates were performed for each biological replicate. 


\subsection{Total RNA Extraction and $c D N A$ Synthesis}

Total RNA was isolated according to Chomczynski and Sacchi [49], except that RNA was precipitated for $2 \mathrm{~h}$ on ice by the addition of 0.3 volume of $10 \mathrm{M} \mathrm{LiCl}$. The isolated RNA was treated with DNase I (Thermo Scientific) and a total of $2 \mu \mathrm{g}$ of RNA was reverse transcribed in a final volume of $10 \mu \mathrm{L}$ using the Transcriptor First Strand cDNA Synthesis Kit (Roche) according to the manufacturer's protocol.

\subsection{Identification of Nucleotide Sequences of Genes Involved in Proline Metabolism and Transport \\ Internal fragments of the analyzed Pisum sativum genes (PsP5CS1, PsP5CS2, PsPDH1,} PsProT1, PsProT2) were amplified using Q5 High-Fidelity DNA Polymerase (New England BioLabs) and primers designed from known sequences of Medicago truncatula P5CS1 (AJ278818), P5CS2 (JN809240), PDH1 (XM_013595747), ProT1 (XM_003600790), and ProT2 (XM_013602264). Primers are listed in Supplementary Table S1. PCR conditions were as follows: $30 \mathrm{~s}$ at $98^{\circ} \mathrm{C} ; 40$ cycles of $10 \mathrm{~s}$ at $98^{\circ} \mathrm{C}, 30 \mathrm{~s}$ at $56^{\circ} \mathrm{C}\left(\right.$ PsPDH1) or $58^{\circ} \mathrm{C}$ (PsP5CS1, PsP5CS2, PsProT1, PsProT2), and $1 \mathrm{~min}$ at $72^{\circ} \mathrm{C}$; followed by a final extension for $10 \mathrm{~min}$ at $72{ }^{\circ} \mathrm{C}$. PCR products were cloned into the pJET1.2/blunt cloning vector (Thermo Scientific), amplified in E. coli JM109, and then sequenced at the DNA Sequencing and Oligonucleotide Synthesis Laboratory at The Institute of Biochemistry and Biophysics, Polish Academy of Sciences. At least six clones of each PCR product were sequenced and analyzed.

\subsection{Gene Expression Analysis}

Real-time PCR was performed on a LightCycler ${ }^{\circledR} 96$ instrument (Roche Diagnostics). The reaction mixture contained $5 \mu \mathrm{L}$ of SYBR Green I Master (Roche Diagnostics), $3 \mu \mathrm{L}$ of cDNA template (equivalent to $10 \mathrm{ng}$ of total RNA), and $0.5 \mu \mathrm{M}$ of each primer in a total volume of $10 \mu \mathrm{L}$. Thermal cycling conditions were as follows: $10 \mathrm{~min}$ at $95^{\circ} \mathrm{C}, 40$ cycles of $15 \mathrm{~s}$ at $95^{\circ} \mathrm{C}, 15 \mathrm{~s}$ at $63^{\circ} \mathrm{C}$, and $20 \mathrm{~s}$ at $72{ }^{\circ} \mathrm{C}$. Melting curves $\left(95^{\circ} \mathrm{C}\right.$ for $10 \mathrm{~s}, 65^{\circ} \mathrm{C}$ for $1 \mathrm{~min}$, and $97^{\circ} \mathrm{C}$ for $1 \mathrm{~s}$ in continuous acquisition mode) were generated for each reaction to ensure amplification specificity. All reactions were performed in triplicate. The relative expression levels of target genes were calculated using the $2^{-\Delta \Delta C t}$ method [50]. The genes encoding $\beta$-tubulin and actin were used as internal controls [51]. The absence of genomic DNA in RNA samples was verified using primers designed to different exons of gene encoding GAPDH (glyceraldehyde-3-phosphate dehydrogenase) [51]. All primers used for real-time PCR are listed in Supplementary Table S2. All reactions were performed at least in triplicate for each of the three biological repetitions.

\subsection{Determination of $A B A$ and Proline Concentrations}

Abscisic acid was extracted from pea tissues as described by Zdunek-Zastocka and Grabowska [52]. Briefly, $200 \mathrm{mg}$ of frozen leaves were ground to a fine powder with liquid nitrogen and mixed with $1.4 \mathrm{~mL}$ of a solution consisting of $80 \%$ methanol, $2 \%$ glacial acetic acid, and butylated hydroxytoluene $\left(20 \mathrm{mg} \mathrm{L}^{-1}\right)$. The extracts were shaken at $4{ }^{\circ} \mathrm{C}$ in the dark for $24 \mathrm{~h}$ and then centrifuged at $12,000 \times \mathrm{g}$ and $4{ }^{\circ} \mathrm{C}$ for $20 \mathrm{~min}$. Supernatants were diluted 25 times in Tris-buffered saline, TBS ( $150 \mathrm{mM} \mathrm{NaCl}, 25 \mathrm{mM}$ Tris-HCl, $\mathrm{pH} 7.5)$, and $100 \mu \mathrm{L}$ of the diluted extracts were used for the quantification of ABA using the Phytodetek ABA enzyme immunoassay test kit (Agida) according to manufacturer's instructions.

Extraction and measurement of free proline in pea tissues were performed according to the acid ninhydrin method described by Bates et al. [53]. Briefly, samples of $100 \mathrm{mg}$ frozen leaves were homogenized with $2 \mathrm{~mL}$ of $3 \%$ sulphosalicylic acid in a pre-chilled mortar and pestle. The extracts were shaken for $30 \mathrm{~min}$ at $750 \mathrm{rpm}$. The residues were removed by centrifugation at $12,000 \times g$ for $20 \mathrm{~min}$. Supernatants $(0.8 \mathrm{~mL})$ were mixed with an equal volume of an acid-ninhydrin reagent $(1.25 \mathrm{~g}$ ninhydrin, $30 \mathrm{~mL}$ of glacial acetic acid, and $20 \mathrm{~mL}$ of $2 \mathrm{M}$ orthophosphoric acid) and incubated for $60 \mathrm{~min}$ in boiling water. After cooling, the reaction mixture was extracted with $2 \mathrm{~mL}$ of toluene, mixed vigorously and left at room temperature for $20 \mathrm{~min}$ until separation of the two phases occurred. The absorbance of toluene phase was measured at $520 \mathrm{~nm}$ using pure toluene as a blank. 


\subsection{Determination of Chlorophyll and MDA Concentrations}

Total chlorophyll was extracted using the dimethyl sulfoxide (DMSO) method described by Hiscox and Israelstam [54]. Frozen pea leaves $(50 \mathrm{mg})$ were mixed with $2 \mathrm{~mL}$ of dimethyl sulfoxide (DMSO) and incubated for $60 \mathrm{~min}$ at $65^{\circ} \mathrm{C}$. The residues were removed by centrifugation at $12,000 \times g$ for $10 \mathrm{~min}$, and the absorbance of the chlorophyll extracts was measured at 649 and $665 \mathrm{~nm}$ against DMSO as a blank.

The amount of malondialdehyde (MDA) was measured according to the thiobarbituric acid test [55]. Samples of $150 \mathrm{mg}$ frozen leaves were homogenized with $1.5 \mathrm{~mL} 0.1 \mathrm{M}$ potassium phosphate buffer, $\mathrm{pH} 6.8$ in a pre-cooled mortar and pestle. The homogenates were centrifuged at $10,000 \times g$ for $15 \mathrm{~min}$. Supernatants were mixed in 1:1 proportions with TBA ( $0.5 \%$ thiobarbituric acid in $15 \%$ trichloroacetic acid) and incubated for $20 \mathrm{~min}$ at $100{ }^{\circ} \mathrm{C}$. After cooling, the solution was centrifuged at $10,000 \times \mathrm{g}$ for $10 \mathrm{~min}$ and the absorbance of the supernatant was measured at $532 \mathrm{~nm}$ and $600 \mathrm{~nm}$.

\subsection{Statistical Analysis}

The statistical analysis was performed using the Statistica 9.1 program. The conformity of data with normal distribution was verified using the Shapiro-Wilk test, and the equality of variances between the two data sets was verified using Levene's test. Thereafter, the parametric Tukey's test (almost all analyses) or the non-parametric Kruskal-Wallis test (analyses of the PSP5CS1 expression under Cd treatment) was used, accordingly.

\section{Results}

\subsection{Identification of Nucleotide Sequences of Genes Involved in the Metabolism and Transport} of Proline

A nucleotide sequence fragment (711 bp), sharing a high percentage identity with the sequences of P5CS1 genes from Medicago truncatula (MtP5CS1, AJ278818, 92\%) [23,56], Medicago sativa (MsP5CS1, X98421, 92\%) [57], Brassica napus (BnP5CS1, AF314811, 75\%), and Arabidopsis thaliana (AtP5CS1, NM_129539, 73\%) [16,22], was identified in pea plants and designated Pisum sativum P5CS1 (PsP5CS1, MW030636) (Supplementary Figure S1).

A 945-bp nucleotide sequence fragment, sharing a high percentage identity with the sequences of P5CS2 genes from Medicago truncatula (MtP5CS2, JN809240, 83\%) [23,56], Arabidopsis thaliana (AtP5CS2; NM_115419, 72\%) [16,22], and Brassica napus (BsP5CS2, AF314812, 67\%), was identified in pea plants and designated Pisum sativum P5CS2 (PsP5CS2, MW423825) (Supplementary Figure S2).

A nucleotide sequence fragment $(471 \mathrm{bp}$ ) that shared a high percentage identity with the sequences of stress-downregulated PDH genes from Medicago truncatula (MtPDH1, XM_013595747, 87\%) [56], Medicago sativa (MsPDH1, AY556386, 80\%; MsPDH2, AY615900, 77\%) [25], Nicotiana tabacum (NtPDH2, AY639146, 69\%) [58], and Arabidposis thaliana (AtPDH1, NM_001339059, 66\%) [59] was identified in pea plants and designated Pisum sativum PDH1 (PsPDH1, MW183670) (Supplementary Figure S3).

A 617-bp nucleotide sequence fragment that shared $84 \%$ identity with the MtProT1 (XM_003600790) and GmProT1 (XM_003552545) genes from Medicago truncatula and Glycine max, respectively, and 70\% identity with the AtProT genes from Arabidopsis thaliana (AtProT1, X95737; AtProT2, X95738; AtProT3, NM_129215) was identified in pea plants and designated Pisum sativum ProT1 (PsProT1, MW030634) (Supplementary Figure S4). The sequence shared less than 60\% identity with the sequences of MtProT2 (XM_013602264) and GmProT2 (XM_014775460). Additionally, a 460-bp nucleotide sequence fragment that shared 88\% identity with the sequence of MtProT2 and $81 \%$ identity with the sequence of GmProT2 was identified in pea plants and designated Pisum sativum ProT2 (PsProT2, MW030635) (Supplementary Figure S5). The sequence shared less than 60\% identity with the sequences of MtProT1, GmProT1, and all three AtProTs. 


\subsection{MDA and Chlorophyll Concentration as Affected by Cadmium Stress}

Levels of chlorophyll and malondialdehyde (MDA), an end product of lipid peroxidation [55], can reflect the degree of stress/membrane damage induced by $\mathrm{Cd}$. Therefore, changes in the chlorophyll $(\mathrm{a}+\mathrm{b})$ and MDA concentrations over time were analyzed in the leaves of pea plants after 12,24 , and $48 \mathrm{~h}$ of growth on media containing $50 \mu \mathrm{M} \mathrm{CdCl}_{2}$. The analyses were performed on leaves at different stages of development: the youngest unexpanded leaves (A), the youngest fully expanded leaves (B1), the fully expanded mature leaves (B2), and the oldest true leaves (C).

Chlorophyll concentration did not change significantly in the leaves of Cd-treated plants after $12 \mathrm{~h}$ (Figure 1A); however, after $24 \mathrm{~h}$, it decreased by $15 \%$ in A and B1 leaves, and by $22 \%$ in $\mathrm{B} 2$ and $\mathrm{C}$ leaves. After $48 \mathrm{~h}$ of $\mathrm{Cd}$ treatment, the concentration of chlorophyll in A and B1 leaves decreased as before, by approximately $15 \%$, while in leaves B2 and C, it declined by $27 \%$ and $36 \%$, respectively.

A

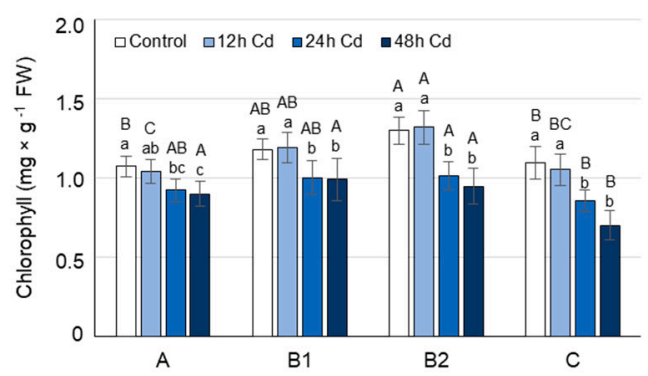

$\mathrm{B}$

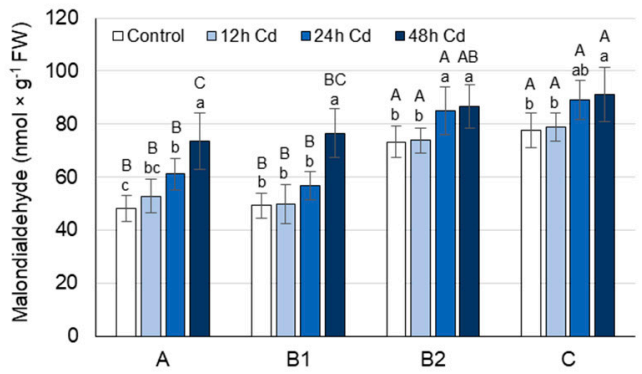

Figure 1. Changes in the chlorophyll (A) and malondialdehyde (B) concentration in the leaves of pea plants exposed to cadmium (Cd) treatment. Cadmium was applied as $50 \mu \mathrm{M} \mathrm{CdCl}_{2}$. A, the youngest unexpanded leaves; B1, the youngest fully expanded leaves; B2, fully expanded mature leaves; and (C), the oldest true leaves. The results are the means ( \pm SD) of three biological replicates. Significant differences (at least $p<0.05$ ) between the means are shown above the columns by different letters: lowercase between different time points in a group of leaves with the same stage of development, and capital between leaves with different stages of development but at the same time point.

Under control conditions, the MDA concentration was approximately 55\% higher in B2 and C leaves than in A and B1 leaves. The MDA concentration did not change significantly in the leaves of pea plants after $12 \mathrm{~h}$ of $\mathrm{Cd}$ stress (Figure $1 \mathrm{~B}$ ); however, after $24 \mathrm{~h}$ of growth on $\mathrm{CdCl}_{2}$, it increased by about $25 \%$ in $\mathrm{A}$ leaves and by $15 \%$ in $\mathrm{B}$ and $\mathrm{C}$ leaves. After $48 \mathrm{~h}$ of $\mathrm{Cd}$ treatment, the MDA concentration increased in A and B1 leaves by approximately $55 \%$, and in B2 and C leaves, as before, by approximately $15 \%$.

\subsection{Proline Concentration and its Metabolism as Affected by Cadmium Stress}

Proline concentration and the expression of genes involved in its metabolism (PSP5CS1, PsP5CS2, PsPDH1) and transport (PsProT2, PsProT2) were studied in the leaves of pea plants after 12,24 , and $48 \mathrm{~h}$ of growth on media containing $50 \mu \mathrm{M} \mathrm{CdCl}_{2}$. The analyses were performed on leaves at various stages of development.

Under control conditions, the highest concentration of proline was found in the youngest undeveloped A leaves, while B1, B2, and C leaves contained approximately 15\%, $35 \%$, and $45 \%$ less proline, respectively (Figure $2 \mathrm{~A}$ ). The highest level of proline in A leaves coincided with the highest transcript level of both PsP5CSs (Figure 2B,C). In contrast to the PsP5CS expression, the mRNA level of PSPDH1 in A leaves was the lowest among leaves at different developmental stages (Figure 2D). A leaf age-specific expression profile similar to that of PsPDH1 was observed for the PsProT1 and PsProT2 genes. Thus, transport of proline from $B$ and $C$ leaves could contribute to the highest proline concentration in the youngest A leaves under control conditions (Figure 3A,B). 
A

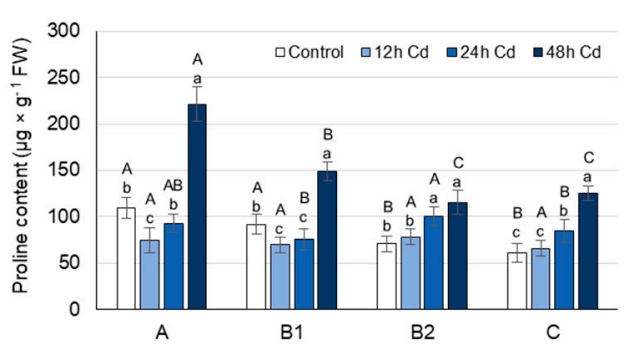

C

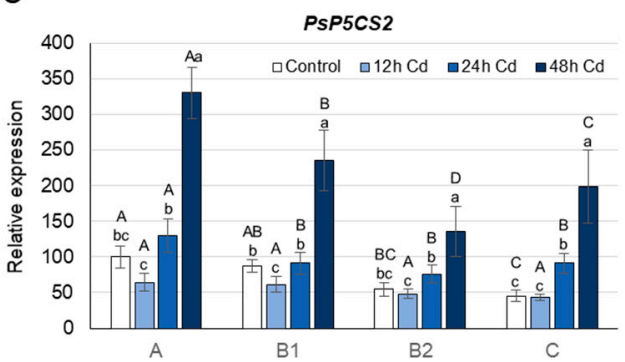

B

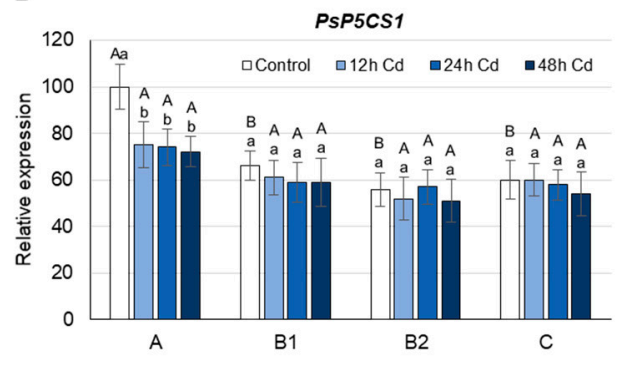

D

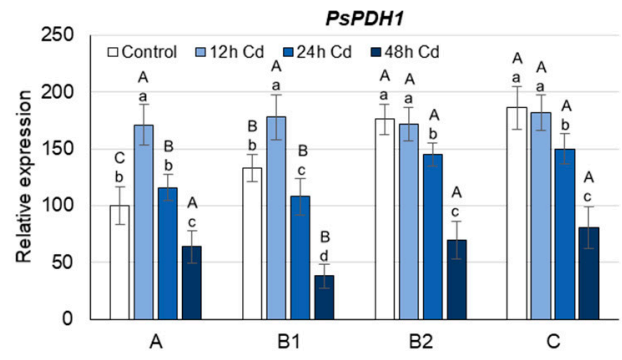

Figure 2. Changes in the proline concentration (A) and transcript level of PsP5CS1 (B), PsP5CS2 (C), and PsPDH1 (D) after 12,24 , and $48 \mathrm{~h}$ of $\mathrm{Cd}$ treatment. Cadmium was applied as $50 \mu \mathrm{M} \mathrm{CdCl}_{2}$. The relative mRNA level in individual leaves was expressed in relation to that in A leaves of control plants, set to 100, after normalization to reference genes. A, the youngest unexpanded leaves; B1, the youngest fully expanded leaves; B2, fully expanded mature leaves; and C, the oldest true leaves. The results are the means $( \pm \mathrm{SD})$ of three biological replicates. Significant differences (at least $p<0.05$ ) between the means are shown above the columns by different letters: lowercase between different time points in a group of leaves with the same stage of development, and capital between leaves with different stages of development but at the same time point.

A

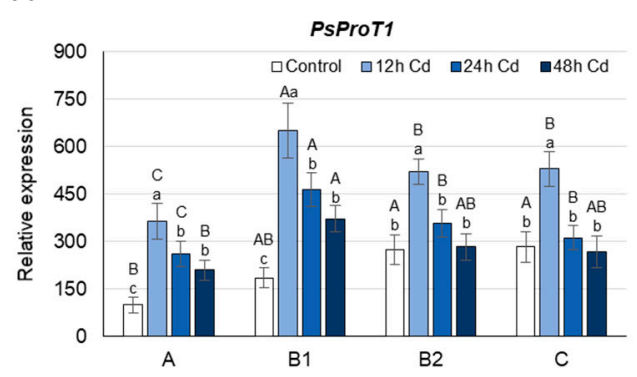

B

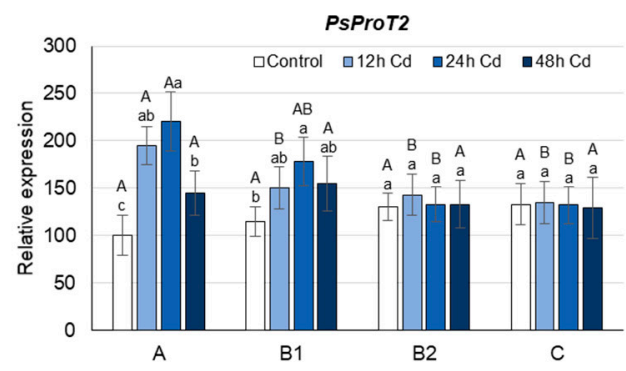

Figure 3. Changes in the transcript level of PsProT1 (A) and PsProT2 (B) after 12, 24, and $48 \mathrm{~h}$ of Cd treatment. Cadmium was applied as $50 \mu \mathrm{M} \mathrm{CdCl}_{2}$. The relative mRNA level in individual leaves was expressed in relation to that in $\mathrm{A}$ leaves of control plants, set to 100, after normalization to reference genes. A, the youngest unexpanded leaves; B1, the youngest fully expanded leaves; B2, fully expanded mature leaves; and C, the oldest true leaves. The results are the means ( \pm SD) of three biological replicates. Significant differences (at least $p<0.05$ ) between the means are shown above the columns by different letters: lowercase between different time points in a group of leaves with the same stage of development, and capital between leaves with different stages of development but at the same time point.

After $12 \mathrm{~h}$ of $\mathrm{Cd}$ stress, the proline concentration decreased by approximately $30 \%$ and $25 \%$ in A and B1 leaves, respectively, while in B2 and C leaves, the proline concentration did not change significantly (Figure 2A). Changes in the proline concentration observed in A and B1 leaves coincided with a 35-30\% decrease in the transcript level of PsP5CS2 in these organs (Figure 2C). In A leaves, additionally, a 25\% decrease of PsP5CS1 transcript level was observed (Figure 2B). The decline in proline concentration observed in A and B1 leaves of Cd-treated plants may also be due to the higher activity of PsPDH1, whose transcript level increased under Cd treatment by $70 \%$ and $35 \%$, respectively (Figure 2D). Cadmium treatment also caused changes in the expression of both PsProTs, especially 
in the young A and B1 leaves, which would contribute to the enhanced translocation of proline from or to these organs (Figure 3A,B). The PsProT1 transcript level increased by approximately $300 \%$ in A leaves, by $150 \%$ in B1 leaves, and by $75 \%$ in $\mathrm{B} 2$ and C leaves, while the PsProT2 mRNA level rose by $100 \%$ and $30 \%$ in A and B1 leaves, respectively, and did not change significantly in $\mathrm{B} 2$ and $\mathrm{C}$ leaves (Figure $3 \mathrm{~A}, \mathrm{~B}$ ).

After $24 \mathrm{~h}$ of growth on the $\mathrm{CdCl}_{2}$ medium, the decrease in proline concentration was observed again in A and B1 leaves; however, the decline was smaller than after $12 \mathrm{~h}$ (Figure 2A). On the other hand, the proline concentration in B2 and C leaves was approximately $35 \%$ higher in Cd-treated plants than in plants grown under control conditions, and was accompanied by $30-40 \%$ higher PsP5CS2 transcript levels in these organs (Figure 2C). The expression of PsP5CS1 was not influenced by Cd ions in B1, B2, or C leaves, while in A leaves, it decreased as after $12 \mathrm{~h}$ of $\mathrm{Cd}$ treatment by $25 \%$ (Figure $2 \mathrm{~B}$ ). The increase in proline concentration observed in B2 and C leaves after $24 \mathrm{~h}$ of $\mathrm{Cd}$ treatment coincided with a $20 \%$ lower level of PsPDH1 mRNA in these organs (Figure 2D). The proline concentration in B2 and $C$ leaves of $C d$-treated plants could also be enhanced by the transport of proline from $A$ and B1 leaves, where the expression of PsProT1 and PsProT2 remained higher by $150 \%$ in the case of ProT1, and by 50-120\% in the case of ProT2. In turn, the level of PsProT1 mRNA in B2 and $C$ leaves was significantly less affected than after $12 \mathrm{~h}$ of $\mathrm{Cd}$ treatment, and the level of PsProT2 mRNA, similarly to $12 \mathrm{~h}$ of Cd stress, did not change significantly (Figure 3A,B).

After $48 \mathrm{~h}$ of Cd stress, an increase in proline concentration was observed in leaves at each stage of development (Figure 2A). In $\mathrm{A}$ and $\mathrm{C}$ leaves, proline concentration in Cdtreated plants was higher than in controls by approximately 100\%, and in B1 and B2 leaves, it was higher than in controls by approximately $65 \%$. Higher proline concentration was accompanied by a higher expression of PsP5CS2 and a lower transcript level of PsPDH1 (Figure 2C,D). The mRNA level of PsP5CS2 increased by more than $200 \%$ in A and C leaves, and by approximately $160 \%$ in $\mathrm{B} 2$ and C leaves, while the transcript level of PsPDH1 decreased by $60-80 \%$ in leaves of each developmental stage. After $48 \mathrm{~h}$ of $\mathrm{Cd}$ stress, the expression of genes encoding proline transporters did not change significantly in B2 or C leaves, while in A and B1 leaves, it was still significantly higher (by $100 \%$ in the case of PsProT1 and by $40 \%$ in the case of PsProT2) than under control conditions (Figure 3A,B).

\subsection{ABA Concentration as Affected by Cadmium Stress}

Under control conditions, the ABA concentration was highest in the youngest A leaves, lower in $B 1$ and $B 2$ leaves, while the oldest $C$ leaves contained only $40 \%$ of the $A B A$ found in A leaves (Figure 4). Under Cd stress, the ABA concentration in pea leaves increased significantly after only $12 \mathrm{~h}$ of treatment, and a similar trend of changes persisted after $48 \mathrm{~h}$ (Figure 4 and Figure S6). The greatest increase in ABA concentration (2.6-fold) was observed in the oldest $C$ leaves, although an approximately 2 -fold increase was also found in B1 and B2 leaves. In A leaves, the ABA concentration only increased by approximately $20 \%$ as a result of $\mathrm{Cd}$ treatment.

\subsection{Proline Concentration and Its Metabolism as Affected by Exogenous $A B A$}

Since the changes in ABA accumulation observed in pea leaves under $\mathrm{Cd}$ stress did not correspond clearly with the observed changes in proline concentration, we investigated the effect of exogenously applied ABA on proline concentration and the expression of genes involved in its metabolism and transport.

During growth on $50 \mu \mathrm{M} \mathrm{ABA}$, a significant increase in proline concentration was observed after only $24 \mathrm{~h}$; however, this occurred exclusively in A leaves (2-fold) and also persisted after $48 \mathrm{~h}$ (Figure 5A) and $72 \mathrm{~h}$ (Supplementary Figure S7). When pea plants were grown on media containing lower concentrations of $\mathrm{ABA}(0.5,5 \mu \mathrm{M})$, an increase in proline concentration was observed again only in A leaves, and it was less significant than during growth on the $50 \mu \mathrm{M}$ ABA (Supplementary Figure S8). Thus, the $50 \mu \mathrm{M}$ concentration of $\mathrm{ABA}$ was selected for the gene expression analyses. After $24 \mathrm{~h}$ of $50 \mu \mathrm{M}$ ABA treatment, the concentration of this hormone increased 2-3 times in A and B leaves, and over 7 times in C 
leaves (Supplementary Figure S9); however, the transcript level of PsP5CS1 did not change significantly in any of these organs (Figure 5B). In turn, the expression of PsP5CS2 increased not only in A leaves (4-fold), where ABA-induced proline accumulation occurred, but also in B (2-fold) and C (4-fold) leaves (Figure 5C). The $50 \mu \mathrm{M}$ ABA treatment decreased the expression of PsPDH1 (except for C leaves) and of PsProT1 in leaves of each developmental stage (Figures 5D and 6A), and increased the transcript level of PsProT2 in A and B1 leaves (Figure 6B). The above analyses show that $\mathrm{ABA}$ induces proline accumulation only in the youngest A leaves; however, its synthesis involving PsP5CS2 can occur in leaves of each developmental stage. At the same time, ABA treatment reduces both proline degradation (except for $\mathrm{C}$ leaves) and proline translocation mediated by PsProT1; however, the transport of proline from or to A and B1 leaves by PsProT2 was increased.

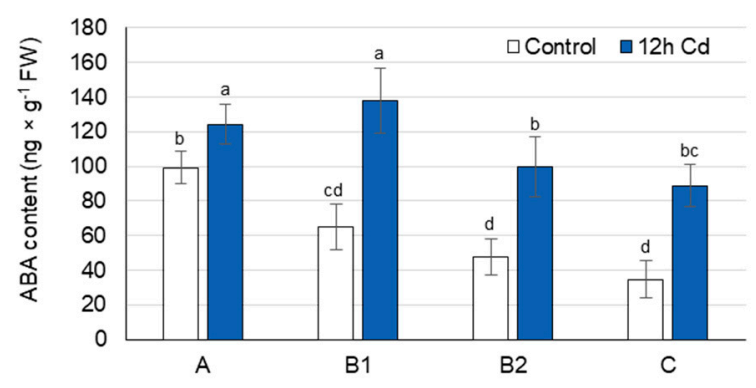

Figure 4. Changes in the abscisic acid concentration after $12 \mathrm{~h}$ of $\mathrm{Cd}$ treatment. Cadmium was applied as $50 \mu \mathrm{M} \mathrm{CdCl}_{2}$. A, the youngest unexpanded leaves; B1, the youngest fully expanded leaves; $B 2$, fully expanded mature leaves; and $C$, the oldest true leaves. The results are the means $( \pm \mathrm{SD})$ of three biological replicates. Different letters above the columns indicate significant differences between the means $(p<0.05)$.

A

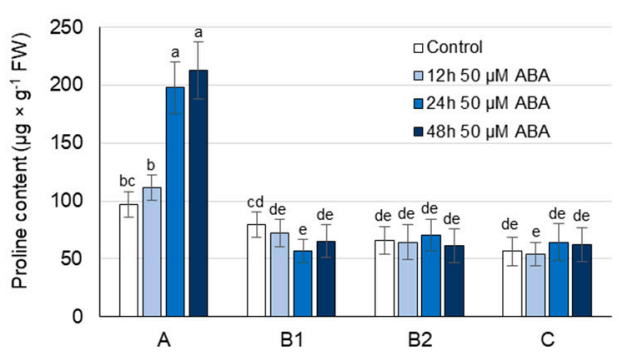

C

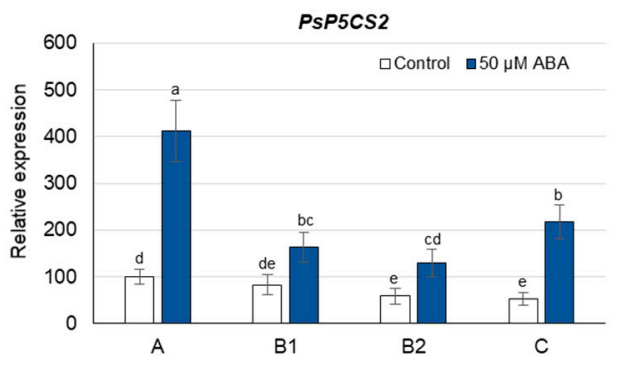

B

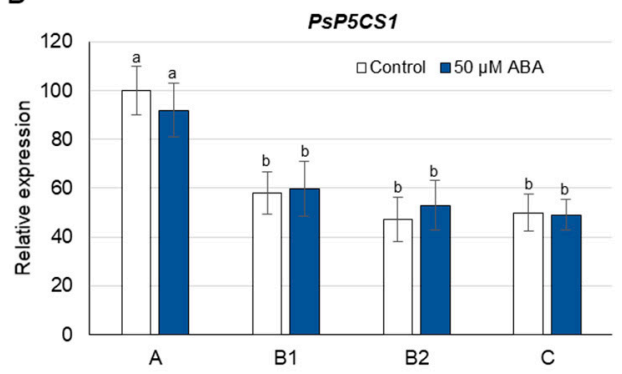

D

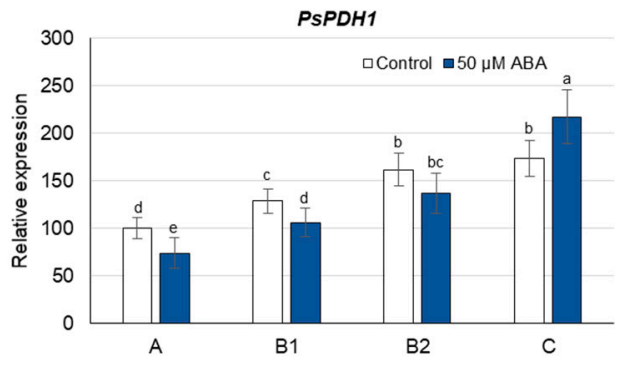

Figure 5. Changes in the proline concentration (A), abscisic acid (ABA) concentration (B), and transcript levels of PsP5CS2 (C) and PsPDH1 (D) after $24 \mathrm{~h}$ of ABA treatment. ABA was applied at a concentration of $50 \mu \mathrm{M}$. The relative mRNA level in individual leaves was expressed in relation to that in A leaves of control plants, set to 100, after normalization to reference genes. A, the youngest unexpanded leaves; B1, the youngest fully expanded leaves; B2, fully expanded mature leaves; and $C$, the oldest true leaves. The results are the means $( \pm \mathrm{SD})$ of three biological replicates. Different letters above the columns indicate significant differences between the means $(p<0.05)$. 
A

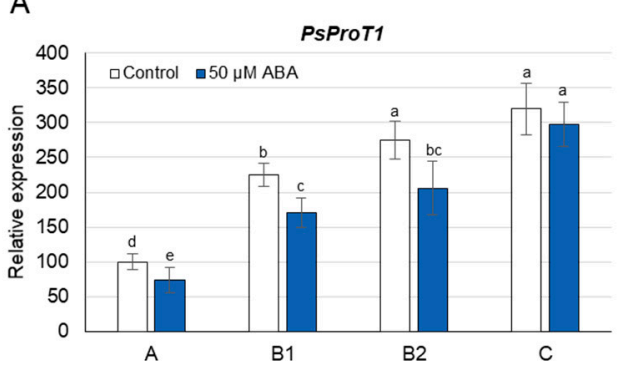

B

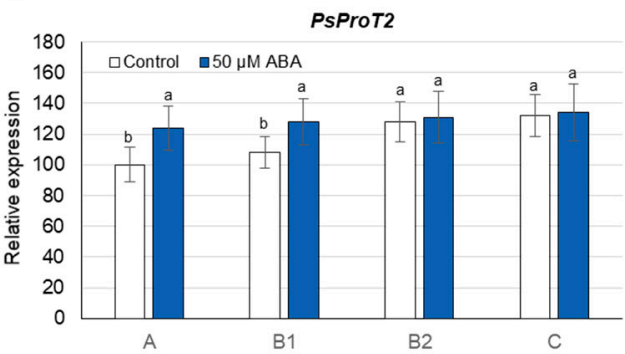

Figure 6. Changes in the transcript levels of PsProT1 (A) and PsProT2 (B) after $24 \mathrm{~h}$ of ABA treatment. ABA was applied at a concentration of $50 \mu \mathrm{M}$. The relative mRNA level in individual leaves was expressed in relation to that in $\mathrm{A}$ leaves of control plants, set to 100, after normalization to reference genes. A, the youngest unexpanded leaves; B1, the youngest fully expanded leaves; B2, fully expanded mature leaves; and C, the oldest true leaves. The results are the means $( \pm S D)$ of three biological replicates. Different letters above the columns indicate significant differences between the means $(p<0.05)$.

\section{Discussion}

The accumulation of free proline varies considerably in different plant organs, depending both on the developmental stage of the plant and on the environmental stimuli $[12,13]$. Proline concentration is usually higher in reproductive organs than in vegetative tissues, and increases significantly in actively dividing cells $[12,29,60]$. When leaves of control pea plants were analyzed according to their stage of development, the highest concentration of proline was found in the youngest undeveloped A leaves, and it gradually decreased through B leaves towards old C leaves (Figure 2A). Similar results were obtained for Brassica napus, where four leaf ranks with gradually increasing source status and gradually decreasing proline concentration were identified from the top to the bottom of the plant axis [61]. In accordance with the observed decrease in proline concentration, the expression of four BnaP5CS1 genes was significantly lower in senescent leaves, which have a strong source leaf status, compared with young growing leaves. In turn, the expression of all BnaP5CS2s did not differ significantly between the individual leaf ranks. In pea plants, the expression of both PSP5CS1 and PsP5CS2 was the highest in the youngest A leaves and decreases towards old C leaves (Figure 2B,C), suggesting the possible contribution of both genes in the high proline concentration of $\mathrm{A}$ leaves. The low proline concentration found in the $\mathrm{C}$ leaves of control plants may also be a result of the transport of proline from these leaves, as well as a higher PsPDH1 expression (Figures 2D and 3). However, when ${ }^{15} \mathrm{~N}$-labeling experiments were performed using $\left[{ }^{15} \mathrm{~N}\right]$ proline and the leaves of Brassica napus, the maximal proline degradation capacity was not different between leaves with very low and very strong source status [61].

Increased proline accumulation is one of the defense mechanisms that plants have developed to counteract the harmful effects of adverse environmental condition stresses such as drought, salinity, and hypoxia $[9,11,62,63]$. Under Cd stress, however, the changes in proline concentration are often contradictory, especially in the leaves [33-37,64]. Therefore, we examined the changes over time of proline concentration in individual leaves, differing in developmental stage and age, during the first $48 \mathrm{~h}$ after the application of $\mathrm{Cd}$ ions.

After $12 \mathrm{~h}$ of $\mathrm{Cd}$ treatment, when the symptoms of damage to cellular structures were not yet observed (Figure 1), a significant decrease in the proline concentration in young A and B1 leaves was noticed (Figure 2A). The decrease in proline concentration was accompanied by a decrease in the transcript level of PSP5CS2, a gene involved in its synthesis, as well as an increased expression of PSPDH1 and PSProTs, genes engaged in its degradation and transport, respectively (Figures 2 and 3). The expression of PSP5CS1 was not influenced by $\mathrm{Cd}$ ions in $\mathrm{B}$ and $\mathrm{C}$ leaves, while in A leaves, it was slightly decreased throughout the entire experimental period (Figure 2B), excluding its key role in the regulation of proline content in response to $\mathrm{Cd}$. In Arabidopsis and Medicago sativa, $\mathrm{PDH}$ is encoded by two genes [24,25]; however, despite many attempts, we were not able to 
identify the second sequence of the $P S P D H$ gene in pea plants. Therefore, it cannot be ruled out that, in addition to PSPDH1, another $P D H$ gene may be involved in the regulation of proline in response to stress factors. Cd is known to disrupt the uptake and movement of mineral nutrients within plants; it predominantly reduces nitrate uptake and mineral transport from root to shoot, as well as inhibits the activity of the enzymes involved in $\mathrm{N}$ assimilation $[5,65]$. A decrease in $\mathrm{NO}_{3}{ }^{-}$uptake and nitrate reductase activity was observed in pea plants as early as $24 \mathrm{~h}$ after Cd supply and was more severe at $50 \mu \mathrm{M}$ than at $10 \mu \mathrm{M}$ $\mathrm{CdSO}_{4}$ [66]. Therefore, in an early plant response to $50 \mu \mathrm{M} \mathrm{Cd}$, a decrease in free proline concentration, which was observed in A and B1 leaves of pea plants (Figure 2A), may result from low nitrogen availability [67]. It can also be triggered by a greater demand for glutamic acid, the product of proline degradation serving as a $\mathrm{N}$ source not only for the synthesis of other amino acids, which are especially needed in young developing leaves, but also for the synthesis of glutathione, certain cofactors, and nucleosides [68]. Moreover, an intensified proline catabolism starting with its oxidation by mitochondrial PDH may provide the energy, in the form of $\mathrm{FADH}_{2}$ and $\mathrm{NAD}(\mathrm{P}) \mathrm{H}[69,70]$, necessary to cope with the negative effects of $\mathrm{Cd}$ toxicity.

After $24 \mathrm{~h}$ of $\mathrm{Cd}$ stress, chlorophyll concentration began to decrease in leaves of all developmental stages, with the greatest declines in B2 and C leaves, while MDA levels began to increase, with the largest rise being observed in A leaves (Figure 1). At that time, the proline concentration was still lower in the A and B1 leaves of Cd-treated plants than in controls; however, in B2 and C leaves, it started to increase (Figure 2A). The changes in proline concentration in $\mathrm{B} 2$ and $\mathrm{C}$ leaves coincided with an elevated expression of PsP5CS2 and a decrease in the PsPDH1 transcript level (Figure 2C,D). After $24 \mathrm{~h}$ of $\mathrm{Cd}$ stress, proline translocation still seems to be important; however, mainly to or from young A and B1 leaves, as a significant increase in the expression of genes related to proline transport was noticeable only in these leaves (Figure 3). It seems that in young A and B1 leaves of Cd-treated plants, proline is still used as a source of nitrogen and energy, while in B2 and $C$ leaves, where the greatest decrease in chlorophyll concentration is noticeable, this amino acid may be necessary to cope with the harmful effects of oxidative stress, which gradually increase after $\mathrm{Cd}$ exposure. Proline has been shown to play a protective role in metal-induced lipid peroxidation and to prevent membrane damage [14].

After $48 \mathrm{~h}$ of Cd stress, when the rate of lipid peroxidation was very high in A and B1 leaves, the proline concentration in these leaves was also higher in Cd-treated plants than in controls (Figures 1 and 2A), which was accompanied by a large increase in the P5CS2 transcript level and a reduction in $P_{s} P D H 1$ expression (Figure 2B,C). Hence, the emerging physiological symptoms of oxidative stress induced by $\mathrm{Cd}$ in $\mathrm{A}$ and $\mathrm{B} 1$ leaves could lead to an equilibrium shift in proline metabolism from the catabolic to the anabolic pathway.

Under drought, salinity, cold, and PEG-induced osmotic stresses, proline accumulation is mediated by both ABA-dependent and ABA-independent signaling pathways [44-47]. Elevated endogenous ABA concentration after $\mathrm{Cd}$ treatment has been detected in Solanum tuberosum [71], Brassica napus [72], Malus hupehensis [73], Typha latifolia, and Phragmites australis [74] plants; however, the relationship between ABA and proline accumulation under $\mathrm{Cd}$ stress is not well understood. Therefore, to investigate a possible mediating role of $\mathrm{ABA}$ in the regulation of proline concentration under $\mathrm{Cd}$ stress, the time courses of $\mathrm{ABA}$ and proline accumulation were first compiled. After $12 \mathrm{~h}$ of $\mathrm{Cd}$ treatment, the ABA concentration increased by $20 \%$ in A leaves and more than doubled in $B$ and $C$ leaves (Figure 4); however, an increase in proline accumulation was not observed in any of these leaves (Figure 2A). In individual leaves, a similar trend of Cd-induced changes of ABA concentration persisted up to $48 \mathrm{~h}$ (Supplementary Figure S6). The proline concentration, however, varied depending on the stage of leaf development, and its increase was first observed after $24 \mathrm{~h}$ in B2 and C leaves, and only after $48 \mathrm{~h}$ in A and B1 leaves. Therefore, an increase in proline concentration in the leaves of $\mathrm{Cd}$-treated pea plants was more highly associated with a decrease in chlorophyll concentration (B2 and C leaves) and an increase in MDA concentration (A and $\mathrm{B} 1$ leaves) than with the elevated level of $\mathrm{ABA}$ alone, at 
least in the first $48 \mathrm{~h}$ of $\mathrm{Cd}$ treatment. Thus, a direct mediating role of $\mathrm{ABA}$ in $\mathrm{Cd}$-induced proline accumulation in leaves of pea plants during the early response to $\mathrm{Cd}$ treatment could be largely excluded. A positive correlation between ABA concentration and proline accumulation was also not observed in leaves of Cd-treated rice plants. After treatment with $\mathrm{Cd}$, the ABA concentration increased in the leaves of the Cd-tolerant rice cultivar, which did not lead to proline accumulation; on the contrary, in the leaves of the Cd-sensitive cultivar, the proline level increased, but not that of ABA [75].

As discussed above, a positive relationship was not always observed between the ABA concentration and the proline accumulation during the early response to $\mathrm{Cd}$ stress in leaves of pea plants; therefore, the effects of exogenously applied ABA on the proline concentration and expression of genes involved in its metabolism and transport were investigated. After 12, 24, 48 and $72 \mathrm{~h}$ of phytohormone application $(0.5,5,50 \mu \mathrm{M})$, the proline concentration only increased in A leaves, accompanied by an elevated expression of PsP5CS2 not only in these organs, but also in B and C leaves (Figure 5A,C, Figures S7 and S8). The transcript level of PsP5CS1 was not affected by Cd application in any of the pea leaves (Figure 5B). Increases in proline concentration and the P5CS transcript level have previously been observed following ABA application in roots of potato (StP5CS1) [71], roots and leaves of Arabidopsis (AtP5CS1) [16,17], and leaves of wheat (P5CS1) [76] and rice (OsP5CS1) [77]. On the other hand, no increase in proline concentration was reported in spinach or pearl millet [47], and wild-type levels of P5CS1 transcripts were found in the ABA-deficient mutant aba2-1, suggesting the ABA-independent regulation of proline synthesis [45]. Thus, the analysis of leaves at different stages of development would provide additional information enabling an understanding of the role of $\mathrm{ABA}$ in the regulation of proline synthesis under $\mathrm{Cd}$ stress. Real-time PCR analyses showed that the transcript level of PsPDH1 was reduced in response to applied ABA in most of the pea leaves (Figure 5D). Similar changes in $P D H$ expression have also been noted in the shoots and roots of Arabidopsis [17] and in seedlings of Brassica napus [78]; however, when rice seedlings were exposed to ABA, the transcript levels of $P D H$ did not change. Moreover, it has also been shown that the $P D H$ promoter in Arabidopsis is induced by exogenously applied Pro but is not affected by ABA [79]. In this way, the $P D H$ response to ABA signals still needs to be thoroughly investigated.

In conclusion, the accumulation of proline during the early response to $\mathrm{CdCl}_{2}$ in leaves of pea plants may occur independently of ABA signaling. The changes in proline concentration observed after $\mathrm{Cd}$ treatment, however, depend on the age of the leaves as well the duration of the stress factor. The concentration of proline in pea leaves is a result of an equilibrium between its synthesis, mediated by PsP5CS2, the catabolism, mediated by PsPDH1, and transport, mediated by PsProT1 and PsProT2. The expression of PsP5CS1, another potential gene involved in proline synthesis, did not correspond to the proline changes during the first $48 \mathrm{~h}$ of $\mathrm{Cd}$ treatment.

Supplementary Materials: The following are available online at https://www.mdpi.com/article/10 .3390/cells10040946/s1: Table S1: Oligonucleotide sequences of Medicago truncatula used as primers for amplification of internal fragments of the Pisum sativum genes, Table S2: Primer sequences used for real-time PCR analysis, Figure S1: The alignment of the nucleotide sequence fragment of Pisum sativum PSP5CS1 (MW030636) with the sequences of P5CS1 genes from other plants, Figure S2: The alignment of the nucleotide sequence fragment of Pisum sativum PsP5CS2 (MW423825) with the sequences of P5CS2 genes from other plants, Figure S3: The alignment of the nucleotide sequence fragment of PSPDH1 (MW183670) with the sequences of stress-downregulated PDH genes from other plants, Figure S4: The alignment of the nucleotide sequence fragment of PsProT2 (MW030635) with the sequences of ProT genes from other plants, Figure S5: The alignment of the nucleotide sequence fragment of PSProT2 (MW030635) with the sequences ProT genes from other plants, Figure S6: Changes in the abscisic acid (ABA) concentration after $48 \mathrm{~h}$ of $\mathrm{Cd}$ treatment, Figure S7: Changes in the proline concentration after $72 \mathrm{~h}$ of abscisic acid (ABA) treatment, Figure S8: Changes in the proline concentration after $24 \mathrm{~h}$ of abscisic acid (ABA) treatment, Figure S9: Changes in the abscisic acid concentration after $24 \mathrm{~h}$ of abscisic acid (ABA) treatment. 
Author Contributions: Conceptualization, E.Z.-Z. and A.G.; methodology, E.Z.-Z. and A.G.; investigation, E.Z.-Z., A.G., B.M. and S.O.; data curation, E.Z.-Z. and A.G.; writing-original draft preparation, E.Z.-Z.; supervision, E.Z.-Z. All authors have read and agreed to the published version of the manuscript.

Funding: S.O. work was partially funded by WULS-SGGW grant number S00125/2020.

Institutional Review Board Statement: Not applicable.

Informed Consent Statement: Not applicable.

Data Availability Statement: The data presented in this study are available on request from the corresponding author.

Conflicts of Interest: The authors declare no conflict of interest.

\section{References}

1. Singh, S.; Parihar, P.; Singh, R.; Singh, V.P.; Prasad, S.M. Heavy metal tolerance in plants: Role of transcriptomics, proteomics, metabolomics, and ionomics. Front. Plant Sci. 2016, 6, 1143. [CrossRef] [PubMed]

2. Colzi, I.; Pignattelli, S.; Giorni, E.; Papini, A.; Gonnelli, C. Linking root traits to copper exclusion mechanisms in Silene paradoxa L. (Caryophyllaceae). Plant Soil 2015, 390, 1-15. [CrossRef]

3. Sychta, K.; Słomka, A.; Kuta, E. Insights into plant programmed cell death induced by heavy metals—discovering a terra incognita. Cells 2021, 10, 65. [CrossRef] [PubMed]

4. Parmar, P.; Kumari, N.; Sharma, V. Structural and functional alterations in photosynthetic apparatus of plants under cadmium stress. Bot. Stud. 2013, 54, 45. [CrossRef] [PubMed]

5. Nazar, R.; Iqbal, N.; Masood, A.; Khan, M.I.R.; Syeed, S.; Khan, N.A. Cadmium toxicity in plants and role of mineral nutrients in its alleviation. Am. J. Plant. Sci. 2012, 3, 1476-1489. [CrossRef]

6. Gouia, H.; Suzuki, A.; Brulfert, J.; Ghorbal, H. Effect of cadmium on the coordination of nitrogen and carbon metabolism in bean seedlings. Plant Physiol. 2004, 160, 367-376. [CrossRef]

7. Cuypers, A.; Smeets, K.; Ruytinx, J.; Opdenakker, K.; Keunen, E.; Remans, T.; Horemans, N.; Vanhoudt, N.; Van Sanden, S.; Van Belleghem, F; et al. The cellular redox state as a modulator in cadmium and copper responses in Arabidopsis thaliana seedlings. J. Plant Physiol. 2011, 168, 309-316. [CrossRef]

8. Żabka, A.; Winnicki, K.; Polit, J.T.; Wróblewski, M.; Maszewski, J. Cadmium (II)-Induced oxidative stress results in replication stress and epigenetic modifications in root meristem cell nuclei of Vicia faba. Cells 2021, 10, 640. [CrossRef] [PubMed]

9. Hayat, S.; Hayat, Q.; Alyemeni, M.N.; Wani, A.S.; Pichtel, J.; Ahmad, A. Role of proline under changing environments. Plant Signal. Behav. 2012, 7, 1456-1466. [CrossRef]

10. Alcázar, R.; Bueno, M.; Tiburcio, A.T. Polyamines: Small amines with large effects on plant abiotic stress tolerance. Cells 2020, 9 , 2373. [CrossRef]

11. Szabados, L.; Savouré, A. Proline: A multifunctional amino acid. Trends Plant Sci. 2010, 15, 89-97. [CrossRef]

12. Kishor, P.B.K.; Sangam, S.; Amrutha, R.N.; Laxmi, P.S.; Naidu, K.R.; Rao, K.R.S.S.; Rao, S.; Reddy, K.J.; Theriappan, P.; Sreenivasulu, N. Regulation of proline biosynthesis, degradation, uptake and transport in higher plants: Its implications in plant growth and abiotic stress tolerance. Curr. Sci. 2005, 88, 424-438.

13. Kishor, P.B.K.; Sreenivasulu, N. Is proline accumulation per se correlated with stress tolerance or is proline homeostasis a more critical issue? Plant Cell Environ. 2014, 37, 300-311. [CrossRef]

14. Sharma, S.S.; Dietz, K.J. The significance of amino acids and amino acid-derived molecules in plant responses and adaptation to heavy metal stress. J. Exp. Bot. 2006, 57, 711-726. [CrossRef]

15. Hossain, M.A.; Hoque, M.A.; Burritt, D.J.; Fujita, M. Proline protects plants against abiotic oxidative stress: Biochemical and molecular mechanisms. In Oxidative Damage to Plants: Antioxidant Networks and Signaling; Ahmad, P., Ed.; Elsevier Inc.: San Diego, CA, USA; London, UK; Waltham, MA, USA, 2014; pp. 477-522.

16. Strizhov, N.; Ábrahám, E.; Ökrész, L.; Blickling, S.; Zilberstein, A.; Schell, J.; Koncz, C.; Szabados, L. Differential expression of two P5CS genes controlling proline accumulation during salt-stress requires ABA and is regulated by $A B A 1, A B I 1$ and $A X R 2$ in Arabidopsis. Plant J. 1997, 12, 557-569. [PubMed]

17. Ábrahám, E.; Rigo, G.; Székely, G.; Nagy, R.; Koncz, C.; Szabados, L. Light-dependent induction of proline biosynthesis by abscisic acid and salt stress is inhibited by brassinosteroid in Arabidopsis. Plant Mol. Biol. 2003, 51, 363-372. [CrossRef] [PubMed]

18. Fabro, G.; Kovács, I.; Pavet, V.; Szabados, L.; Alvarez, M.E. Proline accumulation and AtP5CS2 gene activation are induced by plant-pathogen incompatible interactions in Arabidopsis. Mol. Plant Microbe Interact. 2004, 17, 343-350. [CrossRef] [PubMed]

19. Feng, X.J.; Li, J.R.; Qi, S.L.; Lin, Q.F.; Jin, J.B.; Hua, X.J. Light affects salt stress-induced transcriptional memory of P5CS1 in Arabidopsis. Proc. Natl. Acad. Sci. USA 2016, 113, E8335-E8343. [CrossRef] [PubMed]

20. Aleksza, D.; Horváth, G.V.; Sándor, G.; Szabados, L. Proline accumulation is regulated by transcription factors associated with phosphate starvation. Plant Physiol. 2017, 175, 555-567. [CrossRef] 
21. Kovács, H.; Aleksza, D.; Baba, A.I.; Hajdu, A.; Király, A.M.; Zsigmond, L.; Tóth, S.Z.; Kozma-Bognár, L.; Szabados, L. Light control of salt-induced proline accumulation is mediated by ELONGATED HYPOCOTYL 5 in Arabidopsis. Front. Plant Sci. 2019, 10, 1584. [CrossRef]

22. Székely, G.; Abrahám, E.; Cséplo, A.; Rigó, G.; Zsigmond, L.; Csiszár, J.; Ayaydin, F.; Strizhov, N.; Jásik, J.; Schmelzer, E.; et al. Duplicated P5CS genes of Arabidopsis play distinct roles in stress regulation and developmental control of proline biosynthesis. Plant J. 2008, 53, 11-28. [CrossRef] [PubMed]

23. Armengauda, P.; Thieryc, L.; Buhota, N.; March, G.G.; Savouré, A. Transcriptional regulation of proline biosynthesis in Medicago truncatula reveals developmental and environmental specific features. Physiol. Plant. 2004, 120, 420-450. [CrossRef]

24. Funck, D.; Eckard, S.; Muller, G. Non-redundant functions of two proline dehydrogenase isoforms in Arabidopsis. BMC Plant Biol. 2010, 10, 70. [CrossRef]

25. Miller, G.; Stein, H.; Honig, A.; Kapulnik, Y.; Zilberstein, A. Responsive modes of Medicago sativa proline dehydrogenase genes during salt stress and recovery dictate free proline accumulation. Planta 2005, 222, 70-79. [CrossRef]

26. Hanson, J.; Hanssen, M.; Wiese, A.; Hendriks, M.M.W.B.; Smeekens, S. The sucrose regulated transcription factor bZIP11 affects amino acid metabolism by regulating the expression of ASPARAGINE SYNTHETASE1 and PROLINE DEHYDROGENASE2. Plant J. 2008, 53, 935-949. [CrossRef] [PubMed]

27. Satoh, R.; Fujita, Y.; Nakashima, K.; Shinozaki, K.; Yamaguchi-Shinozaki, K. A novel subgroup of bZIP proteins functions as transcriptional activators in hypoosmolarity-responsive expression of the ProDH gene in Arabidopsis. Plant Cell Physiol. 2004, 45, 309-317. [CrossRef]

28. Nanjo, T.; Fujita, M.; Seki, M.; Kato, T.; Tabata, S.; Shinozaki, K. Toxicity of free proline revealed in an Arabidopsis T-DNA-tagged mutant deficient in proline dehydrogenase. Plant Cell Physiol. 2003, 44, 541-548. [CrossRef]

29. Lehmann, S.; Funck, D.; Szabados, L.; Rentsch, D. Proline metabolism and transport in plant development. Amino Acids 2010, 39, 949-962. [CrossRef] [PubMed]

30. Yao, X.; Nie, J.; Bai, R.; Sui, X. Amino acid transporters in plants: Identification and function. Plants 2020, 9, 972. [CrossRef]

31. Grallath, S.; Weimar, T.; Meyer, A.; Gumy, C.; Suter-Grotemeyer, M.; Neuhaus, J.M.; Rentsch, D. The AtProT family. Compatible solute transporters with similar substrate specificity but differential expression patterns. Plant Physiol. 2005, 137, 117-126. [CrossRef]

32. Guo, N.; Xue, D.; Zhang, W.; Zhao, J.-M.; Xue, C.-C.; Yan, Q.; Xue, J.-Y.; Wang, H.-T.; Zhang, Y.-M.; Xing, H. Overexpression of GmProT1 and GmProT2 increases tolerance to drought and salt stresses in transgenic Arabidopsis. J. Integr. Agric. 2016, 15, 1727-1743. [CrossRef]

33. Zengin, F.K.; Munzuroglu, O. Toxic effects of cadmium $\left(\mathrm{Cd}^{++}\right)$on metabolism of sunflower (Helianthus annuus L.) seedlings. Acta Agric. Scand. B Soil Plant Sci. 2006, 56, 224-229.

34. Talanova, V.V.; Titov, A.F.; Boeva, N.P. Effect of increasing concentrations of lead and cadmium on cucumber seedlings. Biol. Plant. 2000, 43, 441-444. [CrossRef]

35. Zengin, F.K.; Munzuroglu, O. Effects of some heavy metals on content of chlorophyll, proline and some antioxidant chemicals in bean (Phaseolus vulgaris L.) seedlings. Acta Biol. Crac. Ser. Bot. 2005, 47, 157-164.

36. Ali, B.; Gill, R.A.; Yang, S.; Gill, M.B.; Farooq, M.A.; Liu, D.; Daud, M.K.; Ali, S.; Zhou, W. Regulation of cadmium-induced proteomic and metabolic changes by 5-aminolevulinic acid in leaves of Brassica napus L. PLoS ONE 2015, 10, e0123328. [CrossRef]

37. Szalai, G.; Tajti, J.; Hamow, K.A.; Ildikó, D.; Khalil, R.; Vanková, R.; Dobrev, P.; Misheva, S.P.; Janda, T.; Pál, M. Molecular background of cadmium tolerance in Rht dwarf wheat mutant is related to a metabolic shift from proline and polyamine to phytochelatin synthesis. Environ. Sci. Pollut. Res. 2020, 27, 23664-23676. [CrossRef]

38. Nikolic, N.; Kojic, D.; Pilipovic, A.; Pajevic, S.; Krstic, B.; Borisev, M.; Orlovic, S. Responses of hybrid poplar to cadmium stress: Photosynthetic characteristics, cadmium and proline accumulation, and antioxidant enzyme activity. Acta Biol. Crac. Ser. Bot. 2008, 50, 95-103.

39. Iqbal, N.; Umar, S.; Khan, N.A.; Khan, M.I.R. A new perspective of phytohormones in salinity tolerance: Regulation of proline metabolism. Environ. Exp. Bot. 2014, 100, 34-42. [CrossRef]

40. Sharma, A.; Shahzad, B.; Kumar, V.; Kohli, S.K.; Sidhu, G.P.S.; Bali, A.S.; Handa, N.; Kapoor, D.; Bhardwaj, R.; Zheng, B. Phytohormones regulate accumulation of osmolytes under abiotic stress. Biomolecules 2019, 9, 285. [CrossRef]

41. Tong, S.-M.; Xi, H.-X.; Ai, K.-J.; Hou, H.-S. Overexpression of wheat TaNCED gene in Arabidopsis enhances tolerance to drought stress and delays seed germination. Biol. Plant. 2017, 61, 64-72. [CrossRef]

42. Estrada-Melo, A.C.; Ma, C.; Reid, M.S.; Jiang, C.-Z. Overexpression of an ABA biosynthesis gene using a stress-inducible promoter enhances drought resistance in petunia. Hortic. Res. 2015, 2, 15013. [CrossRef]

43. Cao, X.; Wu, L.; Wu, M.; Zhu, C.; Jin, Q.; Zhang, J. Abscisic acid mediated proline biosynthesis and antioxidant ability in roots of two different rice genotypes under hypoxic stress. BMC Plant Biol. 2020, 20, 198. [CrossRef]

44. Verslues, P.E.; Bray, E.A. Role of abscisic acid (ABA) and Arabidopsis thaliana ABA-insensitive loci in low water potential-induced ABA and proline accumulation. J. Exp. Bot. 2006, 57, 201-212. [CrossRef]

45. Savouré, A.; Hua, X.J.; Bertauche, N.; Van Montagu, M.; Verbruggen, N. Abscisic acid-independent and abscisic acid-dependent regulation of proline biosynthesis following cold and osmotic stresses in Arabidopsis thaliana. Mol. Gen. Genet. 1997, 254, 104-109. [CrossRef] 
46. Sharma, S.; Verslues, P.E. Mechanisms independent of abscisic acid (ABA) or proline feedback have a predominant role in transcriptional regulation of proline metabolism during low water potential and stress recovery. Plant Cell Environ. 2010, 33, 1838-1851. [CrossRef]

47. McDonnell, E.M.; Coughlan, S.J.; Wyn Jones, R.G. Differential effects of abscisic acid on glycinebetaine and proline accumulation in three plant species. Z. Panzenphysiol. 1983, 109, 207-213. [CrossRef]

48. Hoagland, D.R.; Arnon, D.I. The water culture method for growing plants without soil. Univ. Calif. Agric. Exp. Stn. Circ. 1938, 347, 1-39.

49. Chomczynski, P.; Sacchi, N. Single-step method of total RNA isolation by a single extraction with an acid guanidinium thiocyanatephenol-chloroform extraction. Anal. Biochem. 1987, 162, 156-159. [CrossRef]

50. Livak, K.J.; Schmittgen, T.D. Analysis of relative gene expression data using real-time quantitative PCR and the $2^{-\Delta \Delta} \mathrm{CT}$ method. Methods 2001, 25, 402-408. [CrossRef] [PubMed]

51. Die, J.V.; Román, B.; Nadal, S.; González-Verdejo, C.I. Evaluation of candidate reference genes for expression studies in Pisum sativum under different experimental conditions. Planta 2010, 232, 145-153. [CrossRef]

52. Zdunek-Zastocka, E.; Grabowska, A. The interplay of PsABAUGT1 with other abscisic acid metabolic genes in the regulation of ABA homeostasis during the development of pea seeds and germination in the presence of $\mathrm{H}_{2} \mathrm{O}_{2}$. Plant Sci. 2019, 285, 79-90. [CrossRef]

53. Bates, L.S.; Waldren, R.P.; Teare, I.D. Rapid determination of free proline for water-stress studies. Plant Soil 1973, 39, 205-207. [CrossRef]

54. Hiscox, J.D.; Israelstam, G.F. A method for the extraction of chlorophyll from leaf tissue without maceration. Can. J. Bot. 1979, 57, 1332-1334. [CrossRef]

55. Heath, R.L.; Packer, L. Photoperoxidation in isolated chloroplast I. Kinetics and stoichiometry of fatty acid peroxidation. Arch Biochem. Biophys. 1968, 125, 189-198. [CrossRef]

56. Verdoy, D.; De La Peña, T.C.; Redondo, F.J.; Lucas, M.M.; Pueyo, J.J. Transgenic Medicago truncatula plants that accumulate proline display nitrogen-fixing activity with enhanced tolerance to osmotic stress. Plant Cell Environ. 2006, 29, 1913-1923. [CrossRef] [PubMed]

57. Ginzberg, I.; Stein, H.; Kapulnik, Y.; Szabados, L.; Strizhov, N.; Schell, J.; Koncz, C.; Zilberstein, A. Isolation and characterization of two different cDNAs of delta (1)-pyrroline-5-carboxylate synthase in alfalfa, transcriptionally induced upon salt stress. Plant Mol. Biol. 1998, 38, 755-764. [CrossRef] [PubMed]

58. Ribarits, A.; Abdullaev, A.; Tashpulatov, A.; Richter, A.; Heberle-Bors, E.; Touraev, A. Two tobacco proline dehydrogenases are differentially regulated and play a role in early plant development. Planta 2007, 225, 1313-1324. [CrossRef] [PubMed]

59. Kiyosue, T.; Yoshiba, Y.; Yamaguchi-Shinozaki, K.; Shinozaki, K. A nuclear gene encoding mitochondrial proline dehydrogenase, an enzyme involved in proline metabolism, is upregulated by proline but downregulated by dehydration in Arabidopsis. Plant Cell 1996, 8, 1323-1335.

60. Zdunek-Zastocka, E.; Grabowska, A.; Branicki, T.; Michniewska, B. Biochemical characterization of the triticale TsPAP1, a new type of plant prolyl aminopeptidase, and its impact on proline content and flowering time in transgenic Arabidopsis plants. Plant Physiol. Biochem. 2017, 116, 18-26. [CrossRef]

61. Dellero, Y.; Clouet, V.; Marnet, N.; Pellizzaro, A.; Dechaumet, S.; Niogret, M.-F.; Bouchereau, A. Leaf status and environmental signals jointly regulate proline metabolism in winter oilseed rape. J. Exp. Bot. 2020, 71, 2098-2111. [CrossRef]

62. Patel, M.K.; Kumar, M.; Li, W.; Luo, Y.; Burritt, D.J.; Alkan, N.; Tran, L.-S.P. Enhancing salt tolerance of plants: From metabolic reprogramming to exogenous chemical treatments and molecular approaches. Cells 2020, 9, 2492. [CrossRef] [PubMed]

63. Naliwajski, M.; Skłodowska, M. The relationship between the antioxidant system and proline metabolism in the leaves of cucumber plants acclimated to salt stress. Cells 2021, 10, 609. [CrossRef]

64. Gutsch, A.; Hendrix, S.; Guerriero, G.; Renaut, J.; Lutts, S.; Alseekh, S.; Fernie, A.R.; Hausman, J.-F.; Vangronsveld, J.; Ann Cuypers, A.; et al. Long-Term Cd exposure alters the metabolite profile in stem tissue of Medicago sativa. Cells 2020, 9, 2707. [CrossRef] [PubMed]

65. Hernández, L.E.; Carpena-Ruiz, R.; Gárate, A. Alterations in the mineral nutrition of pea seedlings exposed to cadmium. J. Plant Nutr. 1996, 19, 1581-1598. [CrossRef]

66. Hernández, L.E.; Gárate, A.; Carpena-Ruiz, R. Effects of cadmium on the uptake, distribution and assimilation of nitrate in Pisum sativum. Plant Soil 1997, 189, 97-106. [CrossRef]

67. Neuberg, M.; Pavlikova, D.; Pavlik, M.; Balik, J. The effect of different nitrogen nutrition on proline and asparagine content in plant. Plant Soil Environ. 2010, 56, 305-311. [CrossRef]

68. Walker, M.C.; van der Donk, W.A. The Many Roles of Glutamate in Metabolism. J. Ind. Microbiol. Biotechnol. 2016, 43, 419-430. [CrossRef] [PubMed]

69. Cabassa-Hourton, C.; Schertl, P.; Bordenave-Jacquemin, M.; Saadallah, K.; Guivarc'h, A.; Lebreton, S.; Planchais, S.; Klodmann, J.; Eubel, H.; Crilat, E.; et al. Proteomic and functional analysis of proline dehydrogenase 1 link proline catabolism to mitochondrial electron transport in Arabidopsis thaliana. Biochem. J. 2016, 473, 2623-2634. [CrossRef]

70. Launay, A.; Cabassa-Hourton, C.; Eubel, H.; Maldiney, R.; Guivarc'h, A.; Crilat, E.; Planchais, S.; Lacoste, J.; Bordenave-Jacquemin, M.; Clément, G.; et al. Proline oxidation fuels mitochondrial respiration during dark-induced leaf senescence in Arabidopsis thaliana. J. Exp. Bot. 2019, 70, 6203-6214. [CrossRef] 
71. Stroiński, A.; Giżewska, K.; Zielezińska, M. Abscisic acid is required in transduction of cadmium signal to potato roots. Biol. Plant. 2013, 57, 121-127. [CrossRef]

72. Yan, H.; Filardo, F.; Hu, X.; Zhao, X.; Fu, D. Cadmium stress alters the redox reaction and hormone balance in oilseed rape (Brassica napus L.) leaves. Environ. Sci. Pollut. Res. Int. 2016, 23, 3758-3769. [CrossRef]

73. Zhang, W.; Wang, Z.; Song, J.; Yue, S.; Yang, H. Cd ${ }^{2+}$ uptake inhibited by MhNCED3 from Malus hupehensis alleviates Cd-induced cell death. Environ. Exp. Bot. 2019, 166, 103802. [CrossRef]

74. Fediuc, E.; Lips, S.H.; Erdei, L. O-acetylserine (thiol) lyase activity in Phragmites and Typha plants under cadmium and NaCl stress conditions and the involvement of ABA in the stress response. J. Plant Physiol. 2005, 162, 865-872. [CrossRef]

75. Hsu, Y.T.; Kao, C.H. Role of abscisic acid in cadmium tolerance of rice (Oryza sativa L.) seedlings. Plant Cell Environ. 2003, 26, 867-874. [CrossRef]

76. Pál, M.; Tajti, J.; Szalai, G.; Peeva, V.; Végh, B.; Janda, T. Interaction of polyamines, abscisic acid and proline under osmotic stress in the leaves of wheat plants. Sci. Rep. 2018, 8, 12839. [CrossRef]

77. Sripinyowanich, S.; Klomsakul, P.; Boonburapong, B.; Bangyeekhun, T.; Asami, T.; Gu, H.Y.; Buaboocha, T.; Chadchawan, S. Exogenous ABA induces salt tolerance in indica rice (Oryza sativa L.): The role of OsP5CS1 and OsP5CR gene expression during salt stress. Environ. Exp. Bot. 2013, 86, 94-105. [CrossRef]

78. Xue, X.; Liu, A.; Hua, X. Proline accumulation and transcriptional regulation of proline biosynthesis and degradation in Brassica napus. BMB Rep. 2009, 42, 28-34. [CrossRef]

79. Nakashima, K.; Satoh, R.; Kiyosue, T.; Yamaguchi-Shinozaki, K.; Shinozaki, K. A gene encoding proline dehydrogenase is not only induced by proline and hypoosmolarity, but is also developmentally regulated in the reproductive organs of Arabidopsis. Plant Physiol. 1998, 118, 1233-1241. [CrossRef] 